\title{
Phytochemical analysis and fungicide potential of Pouteria ramiflora against Lasiodiplodia theobromae
}

\author{
Ademir Kleber M Oliveira; Elvia Silvia Rizzi; Kelly Cristina L Pereira; José Antônio M Bono; José Carlos \\ Pina; Rosemary Matias
}

Universidade Anhanguera-Uniderp, Corguinho-MS, Brasil; akmorbeckoliveira@gmail.com; elviarizzi@hotmail.com; kellykams@hotmail. com; bono@uniderp.edu.br; josecarlos_pina@yahoo.com.br; rosematiasc@gmail.com

\begin{abstract}
The use of plant extracts can be an alternative to reduce the use of pesticides, to control diseases and pests that affect agricultural production. The aim of this study was the chemical characterization of the extract and fractions of Pouteria ramiflora leaves and to determine its fungistatic potential on Lasiodiplodia theobromae. The ethanolic extract of dried and crushed leaves was obtained by maceration. Part of this extract was sequentially partitioned and the following fractions were obtained: hexane, dichloromethane, chloroform, ethyl acetate, n-butyl, and hydromethanol for subsequent bioassay, and qualitative and quantitative phytochemical analysis. Experimental development comprises of adding a $L$. theobromae mycelial disk ( 5 $\mathrm{mm}$ ), obtained from pure colonies, in the middle of Petri dishes with PDA culture growth (potato-dextrose-agar) plus the aforementioned substances in different concentrations $(800 ; 1,200 ; 1,600 ; 2,000$, and $2,400 \mu \mathrm{g} / \mathrm{mL}$ ), and a control treatment (PDA). The plates were incubated in B.O.D. $\left(25 \pm 2{ }^{\circ} \mathrm{C}\right)$, and the assessment was performed by measuring the diameter of the colonies until it reaches the edge of the board. The experimental design was completely randomized with five replications, and the treatments were constituted of a factorial of seven extracts/fractions and six concentrations. For the Mycelial Growth Rate Index (MGRI) obtained, the analysis of variance was performed, and when significant, the regression analysis was performed. All extract/fractions decreased MGRI of L. theobromae, as the concentrations were increased. The best MGRI reduction occurred in n-butanolic fraction, and the efficiency of this fraction may be related to the presence of flavonoids and anthraquinones. The extract and fractions of P. ramiflora, a tree from the Cerrado biome in Mato Grosso do Sul, was effective in the control of $L$. theobromae, which can be used as a control option in organic farming or in integrated management systems.
\end{abstract}

Keywords: Pathogen, natural products, organic farming, flavonoids.

\section{RESUMO}

Fitoquímica e potencial fungistático de extratos e frações de Pouteria ramiflora contra Lasiodiplodia theobromae

O uso de extratos vegetais pode ser uma das alternativas para reduzir o uso de agrotóxicos e controlar doenças e pragas que afetam a produção agrícola. O objetivo deste trabalho foi realizar a caracterização química do extrato e frações das folhas de Pouteria ramiflora e determinar o potencial fungistático sobre Lasiodiplodia theobromae. O extrato etanólico, das folhas secas e trituradas, foi obtido por maceração. Parte desse extrato foi sequencialmente particionado e dele obtidas as frações: hexano, diclorometano, clorofórmio, acetato de etíla, n-butanol e hidrometanólica, submetidos à análise fitoquímica e utilizados nos bioensaios. O desenvolvimento experimental consistiu em adicionar um disco $(5 \mathrm{~mm})$ de micélio de L. theobromae, obtido a partir de colônia pura, no centro de placas de Petri, com meio de cultura BDA (batata-dextrose-ágar) acrescido do extrato e das frações em diferentes concentrações $(800,1.200,1.600,2.000$ e $2.400 \mu \mathrm{g} /$ $\mathrm{mL})$. As placas foram incubadas em B.O.D. $\left(25 \pm 2^{\circ} \mathrm{C}\right)$ e as avaliações realizadas por meio da medição do diâmetro das colônias até atingir a borda da placa. O delineamento experimental foi inteiramente casualizado, com cinco repetições, sendo os tratamentos constituídos do fatorial de sete extratos/frações e seis concentrações, além de um controle (BDA). Os dados do Índice de Velocidade de Crescimento Micelial (IVCM) foram submetidos à análise de variância e quando os resultados foram significativos, foi realizada a análise de regressão. Todos os extrato/frações diminuíram o IVCM de L. theobromae, à medida que se aumentavam as concentrações. A redução mais significativa ocorreu na fração n-butanólica; sua eficiência pode estar relacionada com a presença dos flavonoides e antraquinonas. $\mathrm{O}$ extrato e frações de $P$. ramiflora, uma arbórea do Cerrado Sul-Mato-Grossense, foi eficiente no controle de L. theobromae, apresentando potencial para seu controle em cultivos orgânicos ou em sistemas de manejo integrado.

Palavras-chave: Fitopatógeno, produtos naturais, cultivos orgânicos, flavonoides.

\section{Received on October 20, 2016; accepted on April 17, 2017}

$\mathrm{T}$ The consumer food market is increasingly demanding as to the quality of products and the certainty of the absence of pesticide residues. This is leading growers, horticulturists, and rural extension agencies to apply for registration of plant-derived chemicals by the Ministry of Agriculture, Livestock and Supply (MAPA), for application on small-scale agricultural crops. This is because under Brazilian law there is an insufficient number of registered natural 
ingredients that can cover all crops, which can lead family farmers to the misuse of pesticides (Moreira, 2013).

The use of agrochemicals is related to the different diseases that occur in crops, which reduce the shelf life of fruits and vegetables. In this way, farmers need agricultural pesticides to combat phytopathogens that cause losses during and after production, compromising the quality of these products (Tavares, 2004).

Among the various diseases, fungal diseases are one of the main problems faced. Studies have shown that certain fungi, such as Lasiodiplodia theobromae, an opportunistic or secondary pathogen, have been a problem for production in tropical regions. This pathogen, when it gets inside the tissues of the plant, causes the death of the individual or fall of flowers and fruits of diverse species of economic interest (Junqueira \& Junqueira, 2014).

Among the crops harmed by $L$. theobromae there are some types of vegetables, such as the vinegar Hibiscus sabdariffa (Silva et al., 2014), which leads to losses in production. Lins et al. (2013) report that this fungus is harmful to several fruit crops, such as mango, where it forms dark lesions at the base, with damaged tissues being able to crack, and exposing fruit pulp.

The use of synthetic fungicides is the first option for Brazilian farmers, due to the easiness and predictability of the management employed. However, this practice has promoted several environmental problems and the imbalance of the biological system, in addition to the reduction of biodiversity (Silva et al., 2005).

Given this scenario, the search for alternative substances in the control of pathogens that affect diverse cultures, which are effective, and low in environmental and financial costs is justified. Among these products there are plant extracts, balsams, and oils for controlling the population of fungi and other microorganisms that cause damage to health and agriculture (David et al., 2006). These compounds possess important phytochemicals for the discovery of new substances that are more effective to control species that threaten the production of certain crops.

Among the species that present bioactivity there are the tree species Pouteria ramiflora, found in areas of the Brazilian Cerrado and known as curriola, live-in, or deer-fruit, used in folk medicine for its anti-inflammatory and vermifuge properties (Condessa, 2013), besides having allelopathic action (Oliveira et al., 2014).

Taking into account its potential, this research's objective was to perform the chemical characterization of the extract and fractions of the leaves of Pouteria ramiflora, and to determine its fungistatic potential on Lasiodiplodia theobromae in different concentrations.

\section{MATERIAL AND METHODS}

\section{Vegetable material}

Leaves of Pouteria ramiflora were obtained from 13 matrices in Cerrado areas, Taboco region $\left(20^{\circ} 29^{\prime} 54.47^{\prime \prime} \mathrm{S}\right.$, $55^{\circ} 48^{\prime} 48.49^{\prime \prime} \mathrm{O}$; $19^{\circ} 26^{\prime} 7.60^{\prime \prime} \mathrm{S}$, $\left.55^{\circ} 00^{\prime} 2.78^{\prime \prime} \mathrm{O}\right)$, in Corguinho Municipality, Mato Grosso do Sul. They were collected manually using pruning shears and high pruning shears on $05 / 26 / 2013$, packed in polyethylene bags, and transported in the form of a humid chamber, with specimens herborized, and sent to the herbarium of Laboratory of Plant Morphology, at the Universidade Anhanguera-Uniderp, where after identification, an exemplary has been cataloged, and incorporated to the collection (ID. 7829).

After the exclusion of old and/ or damaged leaves, the collected material was dried at room temperature $\left(27 \pm 2^{\circ} \mathrm{C}\right)$, fragmented with the help of pruning shears, crushed in an electric mill (MARCONI, MA048), and stored in amber glass vial sealed, labeled and stored in a refrigerator, until the preparation of the extracts.

\section{Vegetable extract and partition}

To obtain the crude ethanolic extract $\left(\mathrm{Ext}_{\mathrm{EtOH}}\right)$, leaf powder $(800 \mathrm{~g})$ was extracted with ethanol in an ultrasound device (UNIDQUE, 1450) for 60 minutes, followed by 24 hours of static maceration extraction. This procedure was carried out at ambient temperature until exhaustion (30 days). After filtration, the resulting solutions were concentrated, yielding the crude extract in ethanol from the leaves $\left(\mathrm{Ext}_{\mathrm{EtOH}}\right)$.

Part of the Ext $_{\mathrm{EtOH}}$ was dissolved in ethanol/water (80:20), and successively partitioned with organic solvents of increasing polarity: hexane (hexane fraction $=\mathrm{F}_{\mathrm{Hex}}$ ); dichloromethane (dichloromethane fraction $=\mathrm{F}_{\mathrm{CH} 2 \mathrm{Cl} 2}$ ); chloroform (chloroform fraction $=$ $\mathrm{F}_{\mathrm{CHCl} 3}$ ); ethyl acetate (ethyl acetate fraction $=\mathrm{F}_{\text {Acoet }}$ ), n-butanol (butanolic fraction $=\mathrm{F}_{\mathrm{BuOH}}$ ), and the residue of the partition, hydroethanolic fraction $\left(\mathrm{F}_{\mathrm{H} 2 \mathrm{O} / \mathrm{MeOH}}\right)$.

The partition was employed aiming a semi-purification of the substances through their polarities (Cechinel Filho \& Yunes, 2001).

After removal of the solvents, both Ext $_{\mathrm{EtOH}}$ and the fractions were used for the tests with the fungus $L$. theobromae, and submitted to wet phytochemical analysis, through a series of reactions.

The procedures were: phenolic compounds (precipitation reactions: ferric chloride, lead acetate and copper acetate), tannins (precipitation reactions: iron salts and precipitation of proteins), flavonoids (color change reactions: Shinoda reaction $(\mathrm{Mg} /$ $\mathrm{HCl}$ ) and Taubock), anthocyanins, anthocyanidins and flavonoids (presence of coloration at $\mathrm{pH} \mathrm{2-3,7,8-9} \mathrm{and}$ 11), flavones, flavonoids, flavonoids and xanthones ( $\mathrm{pH} 11)$, chalcones and aurones ( $\mathrm{pH} \mathrm{2-3}$ and 11), coumarins (observation under ultraviolet light), anthraquinones (Borntrager reaction), triterpenes and steroids (LiebermannBurchard reaction), cardiotonic heterosides (Keller-Killiani, Pesez, Baljet and Kedde test), cyanogenic glycosides (reaction of sulfuric acid and picrosodium paper), saponins (presence of foam and LiebermannBurchard reaction), and reducing sugars (Benedict's reaction). The exception to these procedures was the foam index, using $1 \mathrm{~g}$ of the dry extract, to estimate the saponin index (afrosimetric index) (Matos, 2009).

The analyzes were performed in 
triplicate and the results were compared and contrasted, observing the color change and/or precipitation against the control (extract only).

The intensity of the color and/or precipitation is indicative of the high concentration of one of the classes of secondary metabolites present in botanical species. As standards, for samples with intense color and/or precipitation, it was denominated strongly positive $(+++)$, followed by moderately positive $(++)$, weakly $(+)$, partially positive $( \pm=$ with only turbidity and/or partial alteration of color), and the absence of color and/or precipitation as negative (-) (Fontoura et al., 2015).

\section{In vitro biological assay}

The fungus (L. theobromae) used in the in vitro tests was isolated from mango fruits (Mangifera indica), and identified by the colony morphology in the Laboratory of Phytopathology, at the Universidade AnhangueraUniderp. It belongs to the collection of phytopathogenic microorganisms, and was preserved in tubes containing PDA (Potato-dextrose-agar) culture medium in a refrigerator. Seven days before use, it was replicated to Petri dishes containing the PDA medium and placed in B.O.D., at $\pm 25^{\circ} \mathrm{C}$.

For the bioassays, a stock solution of the crude ethanolic extract $\left(\mathrm{Ext}_{\mathrm{ETOH}}\right)$, and each of the fractions $\left(\mathrm{F}_{\mathrm{Hex}} ; \mathrm{F}_{\mathrm{CH} 2 \mathrm{Cl} 2}\right.$; $\mathrm{F}_{\mathrm{CHCl} 3} ; \mathrm{F}_{\text {Acoet }} ; \mathrm{F}_{\mathrm{BuOH}}$ e $\mathrm{F}_{\mathrm{H} 2 \mathrm{O} / \mathrm{MeOH}}$ ) was prepared using $0.2 \mathrm{~g}$ of the samples, and the volume was completed with the respective solvents up to the volume of $100 \mathrm{~mL}$, in volumetric flask.

From the stock solutions of $\mathrm{Ext}_{\mathrm{ETOH}}$ and the fractions, a new dilution was made to obtain a concentration of 500 $\mu \mathrm{g} / \mathrm{mL}$, using a $20 \%$ hydroethanolic solution as solvent, with $5 \mu \mathrm{L}$ of dimethylsulfoxide, which had no toxic effect on mycelial growth of the fungus tested, a result confirmed in the previous test.

These solutions $(500 \mu \mathrm{g} / \mathrm{mL})$ were used in the bioassays, and an aliquot was incorporated into the PDA $( \pm 45$ $\left.{ }^{\circ} \mathrm{C}\right)$, previously autoclaved $\left(120^{\circ} \mathrm{C}\right.$ and $1 \mathrm{~atm}$ for 15 minutes) medium to obtain the concentrations of $800 ; 1,200 ; 1,600$; 2,000 , and $2,400 \mu \mathrm{g} / \mathrm{mL}$, in addition to the pure PDA medium as a control. Subsequently, $10 \mathrm{~mL}$ of the medium with the different concentrations were individually poured into sterile Petri dishes $(87 \mathrm{~mm})$, and then deposited a 0.5 $\mathrm{cm}$ diameter mycelium disc separately from $L$. theobromae, in the center of each plate.

After PVC film sealing, the plates were randomly distributed and remained incubated in B.O.D. at $25 \pm 2{ }^{\circ} \mathrm{C}$; with the aid of a digital caliper, the mycelial growth was evaluated daily by measuring the diameter of the colonies (average of two perpendicular measurements) until reaching the border of the plaque (approximately three days). From the mycelial growth data, the Mycelial Growth Rate Index was calculated:

$$
\left(\mathrm{MGRI}=\frac{\sum(d-d a)}{N}\right)
$$

being the MGRI= mycelial growth rate index, $\mathrm{d}=$ current average diameter of the colony; $\mathrm{da}=$ average diameter of the colony from the previous day and, $\mathrm{n}=$ number of days after inoculation.

The experimental design was completely randomized, with 5 replicates in the factorial of seven extracts/ fractions, and six concentrations, besides the PDA control. Through the data of the Mycelial Growth Rate Index was performed the analysis of variance (ANOVA), and when the results were significant, applied to the regression analysis through the SAS program (SAS, 2001).

\section{RESULTS AND DISCUSSION}

\section{Phytochemical analysis}

Analysis of the ethanolic extract and the fractions showed that the semipurification with solvents of different polarity had the capacity to separate the components present in the leaves of $P$. ramiflora (Table 1).

Ext $_{\text {EtOH }}$ presented the highest diversity of secondary metabolites in relation to fractions, as well as higher phenolic compounds, flavonoids and anthraquinones, except for coumarins, which were predominant in the fraction $\mathrm{F}_{\mathrm{CHCl} 3}$ and saponins, not detected in this extract (Table 1).

The fraction that stands out in relation to the number of classes is hydrometanolic, with six compounds (phenolic compounds, tannins, flavonoids, coumarins, saponins, and reducing sugars). The others presented a number of classes varying between 3 and 4.

The negative results for certain constituents obtained for the fractions do not necessarily imply the absence of the phyto-constituents. When at a scale

Table 1. Phytochemical analyzes of crude ethanolic extract $\left(\mathrm{Ext}_{\mathrm{EtOH}}\right)$ and fractions (Hexane $=\mathrm{F}_{\mathrm{Hex}} ;$ Dichloromethane $=\mathrm{F}_{\mathrm{CH} 2 \mathrm{Cl} 2} ;$ Chloroform $=\mathrm{F}_{\mathrm{CHCl} 13} ;$ Ethyl acetate $=\mathrm{F}_{\text {Acoet }}$; Butanolic $=$ $\mathrm{F}_{\mathrm{BuOH}} ;$ Hydromethanol $=\mathrm{F}_{\mathrm{H} 2 \mathrm{O} / \mathrm{MeOH}}$ ) of Pouteria ramiflora leaves. Campo Grande, AnhangueraUniderp, 2015.

\begin{tabular}{lccccccc}
\hline \multirow{2}{*}{$\begin{array}{l}\text { Classes of secondary } \\
\text { metabolites }\end{array}$} & \multicolumn{7}{c}{ Extracts and fractions } \\
\cline { 2 - 8 } & $\mathbf{E x t}_{\mathrm{EtOH}}$ & $\mathbf{F}_{\mathrm{Hex}}$ & $\mathbf{F}_{\mathrm{CH} 2 \mathrm{Cl} 2}$ & $\mathbf{F}_{\mathrm{CHCl} 3}$ & $\mathbf{F}_{\text {Acoet }}$ & $\mathbf{F}_{\text {BuOH }}$ & $\mathbf{F}_{\text {H2O/MeOH }}$ \\
\hline Phenolic compounds & +++ & + & \pm & ++ & ++ & - & + \\
Tannins & ++ & - & - & - & - & - & ++ \\
Flavonoids & +++ & ++ & - & - & ++ & ++ & + \\
Coumarins & + & - & + & +++ & - & - & + \\
Anthraquinones & +++ & - & - & - & - & +++ & - \\
Triterpenes & +++ & +++ & + & ++ & ++ & - & - \\
Steroids & +++ & +++ & ++ & + & ++ & - & - \\
Saponins & - & - & - & - & - & - & + \\
Reducing sugars & +++ & - & - & - & - & + & +++ \\
\hline
\end{tabular}

$(+)$ lower intensity, $(++)$ average intensity, $(+++)$ greater intensity, $( \pm)$ partial (-) negative result. 
lower than the semimicro, these are not often detected in the qualitative analysis.

According to Zuanazzi \& Montanha (2003), extraction with solvents of different polarities such as hexane has the capacity to remove substances with less polarity (oils, hydrocarbons, furanocoumarines, fats, sterols, and pigments), facilitating the later withdrawal of the other constituents, such as flavonoids, organic halides (dichloromethane followed by chloroform) extract alkaloids, free anthraquinones, cardiotonic heterosides, essential oils, and waxes. In sequence, with higher polarity, ethyl acetate is used, a solvent that removes coumarins, sapogenins, flavonoids, and derivatives of high degree of methylation. The n-butanol extracts the polyhydroxylated aglycones, flavones, and flavonols more polar, aurones, and chalcones. In the aqueous or hydrometanic fraction we managed to find the components with the highest polarity, with heterosides (polyglycosides), mucilages, gum, and pectin, salts of alkaloids, flavanodiols, catechins, procyanidins, and sugars. Based on this information, we observed that the solvents used in the partition were effective in separating the chemical constituents from the Ext $_{\mathrm{EtOH}}$ extract (Table 1).

The main constituents cited for species of the genus are triterpenes (single and long chain, or acetate esters), and flavonoids. Long chain hydrocarbons, alcohols, acids, and esters have also been cited mainly in species that occur in dry regions, such as in savanna areas in Brazil (López, 2005).

The anthraquinones were not recorded for other species of the genus and only recently for the $P$. ramiflora bark, also collected in the Cerrado region of Mato Grosso do Sul (Oliveira et al., 2014). The same authors showed in the extracts analyzed the presence of phenolic compounds, tannins, coumarins, reducing sugars, and saponins besides the free antraquinones, in the inner and outer shells of the aqueous and ethanolic extract, as well as steroids and triterpenes only in the ethanolic extract.

The phenolic compounds were also described for Pouteria caimito,
P. gardneriana, and $P$. campechiana (Canuto et al., 2010; Rocha et al., 2011), and the presence of tannins in the fruits of P. gardneriana (Rocha et al., 2011).

In a recent work, Carriço et al. (2014), investigating the aqueous extract of the leaves of Pouteria sapota found flavonoids, coumarins, cyanogenic glycosides, and reducing sugars as the most abundant classes of secondary metabolites. This information shows the diversity of substances present in

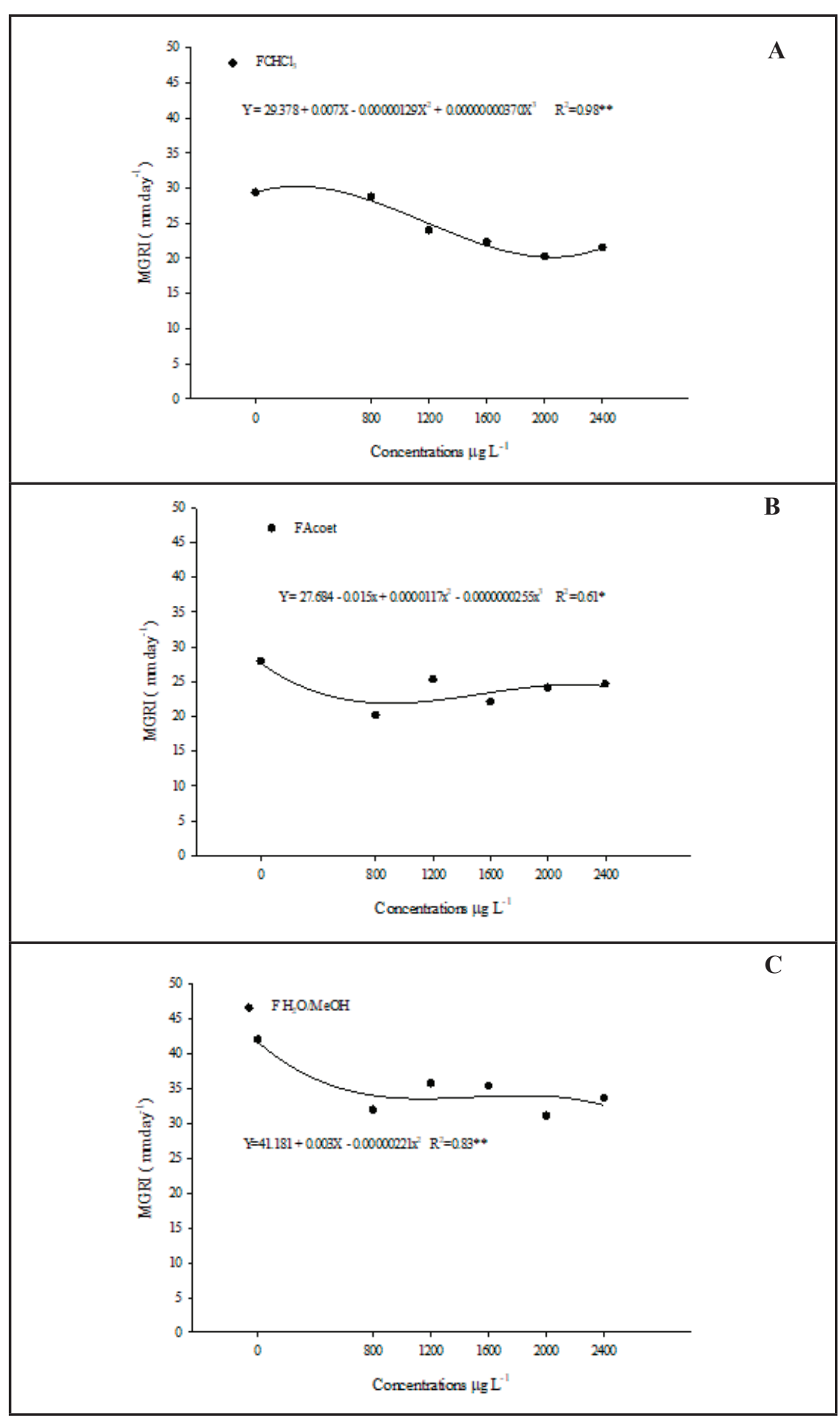

Figure 1. Mycelial Growth Rate Index (MGRI), over 3 days, of Lasiodiplodia theobromae in relation to $\mathrm{F}_{\mathrm{CHCl3}}(\mathrm{A}), \mathrm{F}_{\mathrm{Acoet}}(\mathrm{B})$ and $\mathrm{F}_{\mathrm{H} 2 \mathrm{O} / \mathrm{MeOH}}(\mathrm{C})$ at different concentrations, for leaves of Pouteria ramiflora; *Significant at 5\%,** at 1\% probability. Campo Grande, AnhangueraUniderp, 2015. 


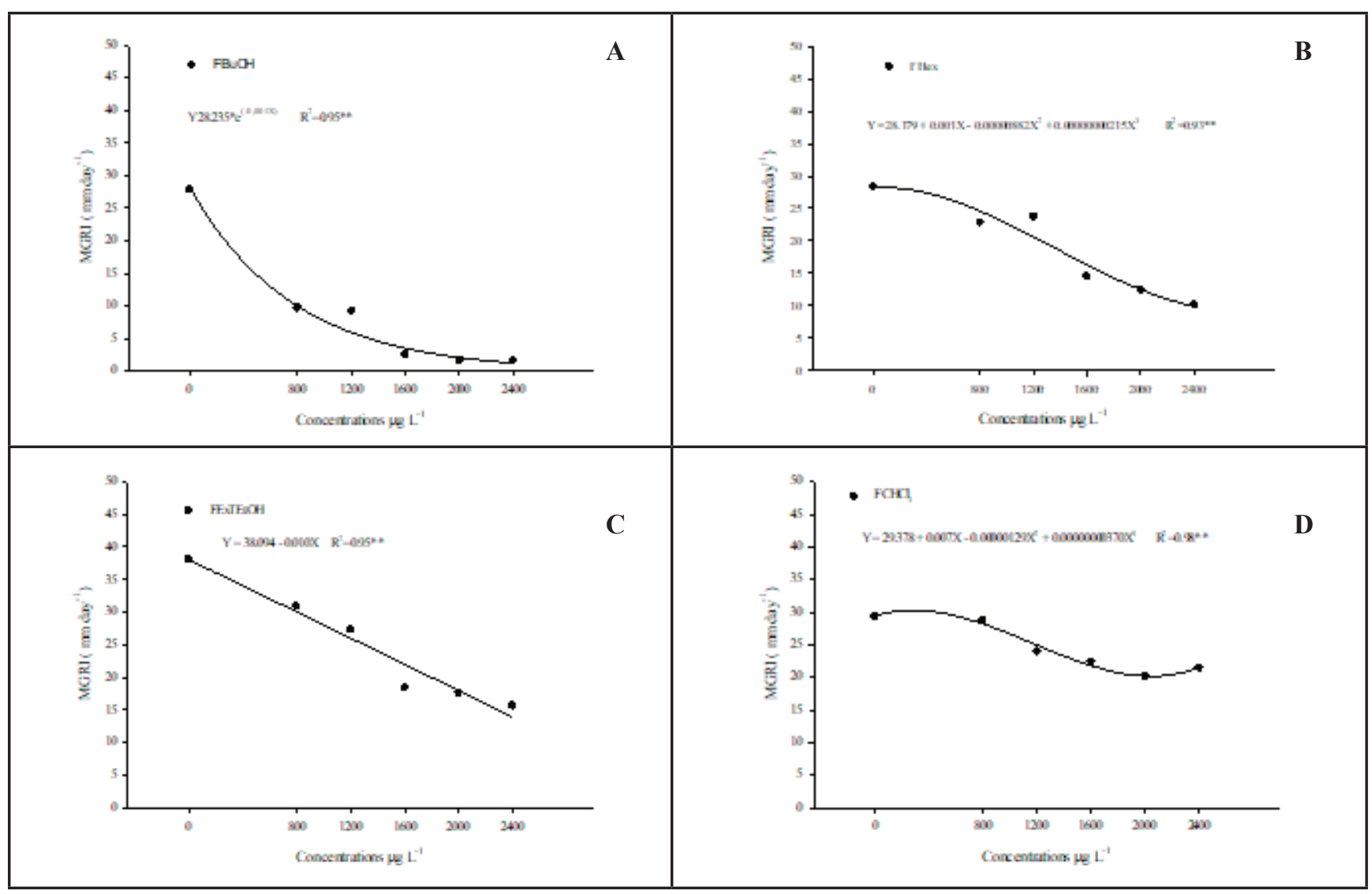

Figure 2. Mycelial Growth Rate Index (MGRI), over 3 days, of Lasiodiplodia theobromae in relation to extract $\mathrm{F}_{\mathrm{BuOH}}(\mathrm{A}), \mathrm{F}_{\mathrm{Hex}}(\mathrm{B}), \mathrm{Ext}_{\mathrm{EtOH}}$ (C) and $\mathrm{F}_{\mathrm{CH} 2 \mathrm{C} 12}$ for Pouteria ramiflora leaves; **Significant at 1\% probability. Campo Grande, Anhanguera-Uniderp, 2015.

species of the genus Pouteria, found in $P$. ramiflora leaves.

\section{Antifungal activity of ethanolic extract and fractions}

According to regression analysis data, fractions $\mathrm{F}_{\mathrm{CHCl}}$ (Figure 1A), $\mathrm{F}_{\text {Acoet }}$ (Figure 1B), and $\mathrm{F}_{\mathrm{H} 2 \mathrm{O} / \mathrm{MeOH}}$ (Figure 1C) produced a decrease in MGRI from the concentration of $800 \mu \mathrm{g} / \mathrm{mL}\left(\mathrm{F}_{\text {Acoet }}\right.$ and $\left.\mathrm{F}_{\mathrm{H} 2 \mathrm{O} / \mathrm{MeOH}}\right)$, and $1,200 \mu \mathrm{g} / \mathrm{mL}\left(\mathrm{F}_{\mathrm{CHCl} 3}\right)$, with values of $\mathrm{F}_{\mathrm{CHC13}}=23.95 \mathrm{~mm} /$ day, $\mathrm{F}_{\text {Acoet }}=20.17 \mathrm{~mm} /$ day, and $\mathrm{F}_{\mathrm{H} 2 \mathrm{O} / \mathrm{MeOH}}=$ $31.95 \mathrm{~mm} /$ day, and controls presenting average values of $30,28.7$ and $42.6 \mathrm{~mm} /$ day, respectively, a reduction between $20.2 \%\left(\mathrm{~F}_{\mathrm{CHCl} 3}\right)$ and $33.3 \%\left(\mathrm{~F}_{\mathrm{H} 2 \mathrm{O} / \mathrm{MeOH}}\right)$ in MGRI. For the higher concentrations, a stabilization trend occurs.

The similarity evidenced in the fungistatic action for fractions with intermediate polarity (fractions $\mathrm{F}_{\mathrm{CHCl3}}$ and $\mathrm{F}_{\text {Acoet }}$ ), despite the variability observed in the chemical analysis of these fractions, is directly related to the antagonism of the chemical composition
(Table 1).

The use of plant extracts and oils with an antagonistic action, and that has the capacity to inhibit the growth of phytopathogens in vitro and in vivo is described by several researchers, such as studies with the extract and essential oil of Piper aduncum, which presented antagonistic activity over the development of Ralstonia solanacearum (Véras \& Yuyama, 2001).

Thus, Silva et al. (2007) used the chloroform and ethyl acetate fractions of Cissus verticillata (Vitaceae) on Cladosporium sphaerospermum, and found that these fractions showed some activity. The major constituent found in the chloroform fraction were the terpenoids, and the active compound of the ethyl acetate fraction, the phenolic compounds.

Unlike the $\mathrm{F}_{\mathrm{CHCl} 13}$ (Figure 1A) and $\mathrm{F}_{\text {Acoet }}$ (Figure 1B) fractions, a more polar fraction $\mathrm{F}_{\mathrm{H} 2 \mathrm{OMeOH}}$ (Figure 1C) has greater diversity of phytochemicals, but less strong, except for reducing sugars (higher intensity $=+++$ ) and tannins $(++)$, in addition to the presence of saponins.

The decrease in the mycelial growth rate of $L$. theobromae can also be observed with aqueous extract of the fresh leaves of five plant species (Gliricidia sepium, Tectona grandis, Ocimum gratissimum, Anacardium occidentale, and Carica papaya) at concentrations of $2.5,5,7.5$ and $10 \%$ $(\mathrm{v} / \mathrm{v})$, and at the times of 3, 5 and 7 days. All extracts inhibited mycelial growth of the fungus even at the lowest concentration, $2.5 \%$, with the time of exposure influencing growth inhibition. The extracts of $O$. gratissimum and A. occidentale were more effective in relation to the other extracts (Agbeniyi \& Ayodele, 2013).

For the $\mathrm{F}_{\mathrm{BuOH}}$ (Figure 2A), $\mathrm{F}_{\mathrm{Hex}}$ (Figure 2B), Ext $\mathrm{EtOH}_{\text {(Figure 2C), and }}$ $\mathrm{F}_{\mathrm{CH} 2 \mathrm{Cl} 2}$ (Figure 2D) fractions, a similar pattern also occurred, with MGRI dropping from the concentration of 800 $\mu \mathrm{g} / \mathrm{mL}$. Afterwards, a gradual decrease 
with a lower MGRI concentration of $2,400 \mu \mathrm{g} / \mathrm{mL}$, with values of $15.65 \mathrm{~mm} /$ day $\left(\operatorname{Ext}_{\mathrm{EtOH}}\right), 10.15 \mathrm{~mm} /$ day $\left(\mathrm{F}_{\mathrm{Hex}}\right)$, $13.98 \mathrm{~mm} /$ day $\left(\mathrm{F}_{\mathrm{CH} 2 \mathrm{CL} 2}\right)$, and $1.67 \mathrm{~mm} /$ day $\left(\mathrm{F}_{\mathrm{BuOH}}\right)$, and controls, 38.7; 27.7; 29.7 , and $28.9 \mathrm{~mm} /$ day, respectively, with reduction between $49.5 \%\left(\mathrm{~F}_{\mathrm{Hex}}\right)$ and $94.2 \%\left(\mathrm{~F}_{\mathrm{BuOH}}\right)$, results higher than those obtained for the fractions $\mathrm{F}_{\mathrm{CHCl} 13}, \mathrm{~F}_{\text {Acoet }}$ and $\mathrm{F}_{\mathrm{H} 2 \mathrm{O} / \mathrm{MeOH}}$, less effective in reducing the MGRI.

The fraction $\mathrm{F}_{\mathrm{BuOH}}$ and $\mathrm{Ext}_{\mathrm{EtOH}}$ have anthraquinones in a higher intensity, which differ from the other solutions. This fraction also showed flavonoids, as well as the $\mathrm{F}_{\mathrm{Hex}}, \mathrm{F}_{\text {Acoet }}$ and $\mathrm{F}_{\mathrm{H} 2 \mathrm{O} / \mathrm{MeOH}}$ fractions. Taking into account that $\mathrm{F}_{\mathrm{BuOH}}$ reduced the mycelial growth rate of $L$. theobromae more intensely, in relation to the other treatments, this may be related to flavonoids and anthraquinones. The same was not observed for the Ext $_{\text {EtOH }}$ extract, probably due to the diversity of constituents present and their interactions, since except for the saponins, the chemical analysis of Ext $_{\mathrm{EtOH}}$ indicated greater diversity and intensity of constituents.

Anthraquinones obtained from natural sources are known to have antibacterial and antifungal activity; specifically to the quinones (reina, aloe-emodina, fisciona, and crisofanol) (Agarwal et al., 2000). This fact is justified by the reason that they have condensed aromatic groups (lipophilic groups), and carboxyl and carboxylic groups, which can also act on membrane rupture and metabolic inhibition. Anthraquinones of natural origin are attributed innumerable activities, with emphasis on the oxidative potential that favors the triggering of cellular apoptosis (cellular suicide); this effect occurs by intercalation between vicinal nucleotides of the DNA strand, via ionic and van der Waals interactions with the anthraquinones, blocking the polymerases and interfering with protein synthesis (Silva et al., 2003; Jampilek, 2015).

Assis (2013), working with ethanolic extracts of $P$. ramiflora (stem and root peels), showed fungitoxic activity on Candida parapsilosis, with values of minimum inhibitory concentration lower than $3.9 \mu \mathrm{g} / \mathrm{mL}$. On the other hand, the dichloromethane extract of the leaves of Echinodorus macrophyllus showed activity on Candida parapsilosis.

Similar results were found in this study with $P$. ramiflora, where in the $\mathrm{F}_{\mathrm{CH} 2 \mathrm{Cl} 2}$ and $\mathrm{F}_{\mathrm{CHCl} 3}$ fractions, the same phyto-constituents occurred, differing only in intensity, especially the terpenes in the $\mathrm{F}_{\mathrm{CH} 2 \mathrm{Cl} 2}$ fraction. The antifungal activity of this fraction is associated with terpenes although its mechanism of action is not well known. To this secondary metabolite class various biological activities in response to physical, chemical or biological stresses are attributed that may inhibit the activity of pathogens (Stangarlin et al., 1999).

By working with hexanic and ethanolic extracts of Pouteria torta, López (2005), reported microbial activity against $S$. aureus, a result similar to those found by this work.

In a study with the hexane and n-butanolic fractions of Cissus verticillata, Silva et al. (2007) showed no antifungal activity against Cladosporium sphaerospermum, different from that found in this study where the same hexanic and n-butanolic fractions of $P$. ramiflora showed fungitoxic action on L. theobrome, decreasing its MGRI.

The difference in the spectrum of fungistatic activity of the ethanolic extract and fractions, and their greater or lesser activity, may be due to three reasons: firstly, the polarity of the ethanolic extract and fractions that select phytochemicals with different affinities in the receptors of the fungus L. theobromae; secondly, the active compound may be present in an insufficient amount in the fractions that had the MGRI lower than the $\mathrm{Ext}_{\mathrm{EtOH}}$ extract, and the $\mathrm{F}_{\mathrm{Hex}}, \mathrm{F}_{\mathrm{CH} 2 \mathrm{Cl} 2}$ and $\mathrm{F}_{\mathrm{BuOH}}$ fractions; therefore, the dose level used is insufficient; and third, if the active principle is present in the $\mathrm{Ext}_{\mathrm{EtOH}}$ extract and the fractions; but other constituents are exerting antagonistic effects of the bioactive.

The results obtained indicated that the extracts and fractions of the leaves of $P$. ramiflora were appropriate in controlling the fungus $L$. theobromae, with the lowest rate of mycelial growth observed in the concentration of 2,400 $\mu \mathrm{g} / \mathrm{mL}$. The butanolic fraction was the most efficient and this activity can be related to the flavonoids and anthraquinones present in this fraction, and their interactions.

These results indicate that the use of extracts of $P$. ramiflora present potential for pathogen control in organic crops or in integrated management systems, due to their chemical constituents and generated interactions. In this way, it can reduce fungal infection in different crops, such as the production of fruits, vegetables, ornamental and condiment plants, generating lower losses for the producers, and reducing the risks of food contamination due to a more restricted use of certain chemical products.

However, tests with the application of these extracts and fractions, in the greenhouse, and later in the field are necessary to evaluate this potential in vivo, in addition to seeking a more indepth analysis of the butanolic fraction, and its mode of action, allowing the understanding of its effective action in controlling the pathogen tested.

\section{ACKNOWLEDGMENTS}

We would like to acknowledge the Coordination for the Improvement of Higher Education Personnel (CAPES) for the master's and doctoral scholarships, as well as the National Council for Scientific and Technological Development (CNPq), for the grants of productivity in research (PQ2) and scientific initiation (PIBIC). We also would like to acknowledge the financial support of CNPq, Pantanal Research Center (CPP), National Institute of Science and Technology in Wetlands (INAU), Foundation for Support, and Development of Education, Science and Technology of the State of Mato Grosso do Sul (FUNDECT), and the University Anhanguera-Uniderp for funding the Interdisciplinary Research Group (GIP) project.

\section{REFERENCES}

AGARWAL, SK; SINGH, SS; VERMA, S; 
KUMAR, S. 2000. Antifungal activity of anthraquinone derivatives from Rheum emodi. Journal of Ethnopharmacology 72: 43-46.

AGBENIYI, SO; AYODELE, MS. 2013. Efficacy of plant leaf extracts on the mycelial growth of kolanuts storage pathogens, Lasiodioplodia theobromae and Fusarium pallidoroseum. African Journal of Agricultural Research 8: 2730-2732.

ASSIS, PA. 2013. Atividade antifúngica de extratos depositados no banco de extratos de plantas do bioma cerrado e de substâncias isoladas de Matayba guianensis. Brasília: UNB. 168p (Dissertação mestrado).

CANUTO, GAB; XAVIER, AAO; NEVES, LC; BENASSI, MT. 2010. Caracterização físicoquímica de polpas de frutos da Amazônia e correlação com a sua atividade anti-radical livre. Revista Brasileira de Fruticultura 32: 1196-1205.

CARRIÇO, C; PINTO, ZT; DUTOK, CMS; CAETANO, RL; PESSANHA, RR; CHILNUÑEZ, I; MENDONÇA, PM; ESCALONAARRANZ, JC; REYES-TUR, B; QUEIROZ, MMC. 2014. Biological activity of Pouteria sapota leaf extract on post-embryonic development of blowfly Chrysomya putoria (Wiedemann, 1818) (Calliphoridae). Revista Brasileira de Farmacognosia 24: 304-308.

CECHINEL FILHO, V; YUNES, RA. 2001. Estudo químico de plantas medicinais orientado para análise biológica. Obtenção, determinação e modificação estrutural de compostos bioativo. In: YUNES, RA; CALIXTO, JB. (eds). Plantas medicinais sob a ótica da química medicinal moderna. Chapecó: Argos. p.47-75.

CONDESSA, MB. 2013. Avaliação da atividade antioxidante e alelopática de plantas medicinais. BioFarm 9: 1983-4209.

DAVID, EFS; BOARO, CSF; MARQUES, MOM. 2006. Rendimento e composição do óleo essencial de Mentha piperita L., cultivada em solução nutritiva com diferentes níveis de fósforo. Revista Brasileira de Plantas Medicinais 8: 183-188.

FONTOURA, FM; MATIAS, R; LUDWIG, J; OLIVEIRA, AKM; BONO, JAM; MARTINS, PFRB; CORSINO, J; GUEDES, NMR. 2015. Seasonal effects and antifungal activity from bark chemical constituents of Sterculia apetala (Malvaceae) at Pantanal of Miranda, Mato Grosso do Sul, Brazil. Acta Amazonica 45: 283-292.

JAMPILEK, J. 2015. Potential of agricultural fungicides for antifungal drug discovery. Expert Opinion on Drug Discovery 11: 1-9.

JUNQUEIRA, NTV; JUNQUEIRA, KP. 2014. Principais doenças de anonáceas no Brasil: descrição e controle. Revista Brasileira de Fruticultura 36: 55-64.

LINS, SRO; MELO, AP; OLIVEIRA, SMA. 2013. Podridão peduncular em manga: patogenicidade, agressividade e caracterização de isolados pela análise isoenzimática. Summa Phytopathologica 39: 263-270.

LÓPEZ, KSE. 2005. Estudo químico e atividade biológica de Pouteria torta (Mart.) Radlk. (Sapotaceae). Brasília: UNB. 74p (Dissertação mestrado).

MATOS, FJA. 2009. Introdução a fitoquímica experimental. Fortaleza: UFC. 150p.

MOREIRA, MRS. 2013. Um olhar sobre a agricultura familiar, a saúde humana e o ambiente. Ciência e Cultura 65: 53-57.

OLIVEIRA, AKM; PEREIRA, KCL; MULLER, JAI; MATIAS, R. 2014. Análise fitoquímica e potencial alelopático das cascas de Pouteria ramiflora na germinação de alface. Horticultura Brasileira 32: 41-47.

ROCHA, WS; LOPES, RM; SILVA, DB; VIEIRA, RF; SILVA, JP; AGOSTINI-COSTA, TDS. 2011. Compostos fenólicos totais e taninos condensados em frutas nativas do cerrado. Revista Brasileira de Fruticultura 33: 12151221.

SAS Institute. SAS user's guide: statistics, version
8.2. 2001. 6. ed. Cary: Todd and Browde.

SILVA, GS; RÊGO, AS; LEITE, RR. 2014. Doenças da vinagreira no Estado do Maranhão. Summa Phytopathologica, 40: 378-380.

SILVA, JM; NOVATO-SILVA, E; FARIA, HP; PINHERO, TMM. 2005. Agrotóxico e trabalho: Uma combinação perigosa para saúde do trabalhador rural. Ciência \& Saúde Coletiva 10: 891-903.

SILVA, L; ONIKI, GH; AGRIPINO, DG; MORENO, PRH; YOUNG, MCM; MAYWORM, MAS; LADEIRA, AM. 2007. Biciclogermacreno, resveratrol e atividade antifúngica em extratos de folhas de Cissus verticillata (L.) Nicolson \& Jarvis (Vitaceae). Revista Brasileira de Farmacognosia 17: 361-367.

SILVA, MN; FERREIRA, VF; SOUZA, MCBV. 2003. Um panorama atual da química e da farmacologia de naftoquinonas, com ênfase na beta-lapachona e derivados. Química Nova 26: 407-416.

STANGARLIN, JR; SCHWAN-ESTRADA, KRF; CRUZ, MES; NOZAKI, MH. 1999. Plantas medicinais e controle alternativo de fitopatógenos. Biotecnologia Ciência \& Desenvolvimento 11:16-21.

TAVARES, GM. 2004. Controle químico e hidrotérmico da antracnose em frutos de mamoeiro (Carica papaya L.) na pós-colheita. Lavras: UFLA. 55p (Dissertação mestrado).

VÉRAS, SM; YUYAMA, K. 2001. Atividade antagônica in vitro do óleo essencial e extrato de pimenta-longa (Pipper aduncum), no crescimento de Ralstonia solanacearum Raças 1 e 2. Fitopatologia Brasileira 26: 274.

ZUANAZZI, JA; MONTANHA, JA. 2003. Flavonóides. In: SIMÕES, CMO; SCHENKEL, EP; GOSMANN, G; MELLO, JCP; MENTZ, LA; PETROVICK, PR. (eds). Farmacognosia: da planta ao medicamento. Florianópolis/Porto Alegre: UFSC/UFRGS. p.577-614. 